\title{
The relationship between homicides reported by printed media and official records in Costa Rica, and a test of the Duntley-Buss Biological Model of Murder
}

\author{
Julián Monge-Nájera and Karla Vega Corrales \\ Laboratorio de Ecología Urbana, Vicerrectoría de Investigación, Universidad Estatal a Distancia, 2050 San José, Costa Rica; \\ julianmonge@gmail.com,kantr.vega@gmail.com
}

Recibido 17-I-2012 Corregido 2-III-2012 Aceptado 28-III-2012

\begin{abstract}
Studies about homicides in Costa Rica have not been systematic and have dealt mostly with homicide rates, mode of death, identity of victims and murderers, place and time of death, and relationship with drugs. None dealt with biological models of homicide. The goals of this study were to compare press reports with official statistics, to evaluate several hypotheses about when homicides occur and to analyse the Costa Rican murder scene from the point of view of the Duntley \& Buss biological model. We recorded all homicides mentioned in two Costa Rican newspapers (La Nación and Diario Extra) from January 1 through December 31, 2008 and extracted the corresponding statistical data from the Costa Rican Judicial Branch for comparison. Both newspapers reported data that were in agreement with official statistics. Our hypothesis that mortality was higher in the months with long holidays was rejected. Men have a higher probability of dying from fire weapon wounds and women from smothering. Limón province has a higher homicide rate, as do Colombian, Panamanian and Nicaraguan immigrants. All our results are in agreement with the Duntley \& Buss biological model.
\end{abstract}

\section{KEY WORDS}

Scientific model of murder, Latin American security scene, crime in Central America, biological causes of murder, sexual strategies.

\section{RESUMEN}

Los estudios sobre homicidios en Costa Rica no ha sido sistemáticos y se han ocupado sobre todo de tasas de homicidio, el modo de muerte, identidad de las víctimas y asesinos, lugar y hora de la muerte y relación con las drogas. Ninguno ha considerado los modelos biológicos de homicidio. El objetivo de este estudio fue comparar los informes de la prensa con las estadísticas oficiales, para evaluar varias hipótesis acerca de cuándo se producen los homicidios y analizar el asesinato en Costa Rica desde el punto de vista del modelo biológico de Duntley \& Buss. Registramos todos los homicidios mencionados en dos periódicos de Costa Rica (La Nación y Diario Extra) del 1 de enero al 31 de diciembre de 2008 y los comparamos con las estadísticas oficiales del Poder Judicial. Ambos diarios informaron de manera coherente con las estadísticas oficiales. Rechazamos nuestra hipótesis de que la mortalidad era mayor en los meses con muchos días libres. Los hombres tienen una mayor probabilidad de morir por arma de fuego y las mujeres por asfixia provocada. La Provincia de Limón tiene una tasa de homicidios más alta, al igual que los inmigrantes colombianos, panameños y nicaragüenses. Todos los resultados están de acuerdo con el modelo biológico de Buss y Duntley.

\section{PALABRAS CLAVE}

Modelo científico del asesinato, seguridad en América Latina, delincuencia en América Central, causas biológicas del asesinato, estrategias sexuales

\section{INTRODUCTION}

Studies about homicides and social perception of insecurity in Costa Rica have not been systematic. There were three studies in the decade of 1990 that we know of. When compared with the USA, Costa Rica as found to have lower suicide and homicide rates, and a lower use of firearms (hanging being more common for suicide and cutting/ piercing for homicide). Another difference was that suicide rates do not increase with age but the chances of being murdered do (Lester 1995).

A comparison of eight cities from Spain and Latin America, including San José, Costa Rica, found that even though sex, age and alcohol consumption correlate with homicide victims, the victimization rates vary with the city 
(Cruz 1999). The decade closed with specific interest in femicide (Sagot \& Carcedo 2010).

There was an increase in the number of studies in the first half of the 2000 decade. It was stated that the media reinforced patriarchal prejudice and stereotype against women who suffered from domestic violence that sometimes ends in homicide (Aguilar 2001) and that some women found more violence at home than outside it. Life-threatening attacks against women were done mainly with knives (31\%) while guns represented only $15 \%$ of cases (Carcedo \& Sagot 2002). Furthermore, two thirds of murdered women died at the hands of their partners or relatives (Anfossi 2002). Other studies of the period suggested that the high consumption expectations of young men, mixed with their economic disadvantages, led to the use of violence (Briceño-León 2002).

The number of studies increased significantly after 2005 and was marked by a renewed interest in the causes of homicide and recognition that, despite the undeniable importance of femicide, the majority of homicide victims are men. Furthermore, weekends and the province of $\mathrm{Li}$ mon were found to have the highest rates of voluntary manslaughter (Sáenz 2006). A later study corroborated those results and added that weekends, location (port cities, capitol city), using alcohol or other drugs and being in the economically productive age were frequent characteristics for homicide victims (Sanabria et al. 2009). Similarly, a study that compared Costa Rica with the rest of Latin America, concluded that the country has a relatively low homicide rate and that social inequalities, lack of employment opportunities, urban segregation, a culture of masculinity, local drug markets, the availability of firearms and widespread use of alcohol can explain homicide rates (Briceño-León et al. 2009). It was also found that, compared to Costa Ricans, Nicaraguan-born immigrants have homicide as a major source of excess mortality (Herring et al. 2008).

The public view of homicide as a social problem is shaped by the media. A comparison of El Salvador, Nicaragua and Costa Rica found strong relations and mutual influences between the public's fear (or disregard) of youth violence and the state's policies to reduce it (Peter 2008). In line with this, the Costa Rican talk of crime assumes that a formerly explicitly nonviolent nation has changed and calls for zero tolerance and drastic law enforcement actions. The pervasive feelings of insecurity and social pessimism appear to reflect a political influence after the shift in economic and social-welfare politics that followed the 1980s crisis in the economy (Huhn 2009).

The purpose of this study is to evaluate several hypotheses about real homicide rates in Costa Rica, a Central
American country. We compare official records with the information that the media provide to the public, considering the factors of victim sex, type of weapon, as well as economic status and nationality of the victims within the framework of the Duntley-Buss Biological Model of Murder.

\section{METHODOLOGY}

We recorded all homicides mentioned in two Costa Rican newspapers (La Nación and Diario Extra) from January 1 through December 31, 2008 and extracted statistical data from the Costa Rican Judicial Branch (Organismo de Investigación Judicial internal report for 2008).

La Nación is a general newspaper that presents the right wing view of the news and has a small police section (Sucesos), while Diario Extra targets the economically lowest social group of readers and has a more extended Police section (also called Sucesos).

\section{Hypotheses}

Our hypotheses were:

1. The media reports homicide statistics different from the official statistics

2. Homicides are more frequent in the months with more holidays

3. Firearms are used more frequently when the victims are male

4. Women are more likely to be killed by suffocation

5. The homicide rates are higher in the poorer provinces of Limón and Puntarenas

6. Nicaraguans and Colombian residents have higher homicide rates than Costa Ricans

Large tables were reorganized by trimester for the ChiSquared analysis according to Zar (1998). Population data are from the 2000 national census (INEC http://www.inec. go.cr/Web/Home/GeneradorPagina.aspx)

\section{RESULTS}

The number of homicides mentioned by both newspapers was similar to the data in the official government report (Chi-squared Test $0.38 p=0.98$ ). The number of males murdered increased in March and again from April through August, for a final peak in December (Fig. 1). Our hypothesis that mortality was higher in April and 
December, the months with long holidays, is rejected for December (Fig. 1).

The number of female homicide victims mentioned by both newspapers was lower but not significantly different from the official report (Chi-squared Test $0.76 p=0.9437$, Fig. 2).

In contrast with males, the number of females murdered varied greatly in the first half of the year and was lower in the second, in complete disagreement with our hypothesis of higher mortalities in April and December Fig. 2).

\section{Use of fire weapons}

The number of males murdered with fire weapons reported by both newspapers was similar to the number in the official report (Chi-squared Test 0.5, $p=0.9735$ ). After a peak in March, there was a marked increase in June and the number gradually fell until November, which was followed by a high number in December. In general, the second half of the year has more victims (Fig. 3).

The number of females murdered with fire weapons was too low for a significant monthly trend analysis, but again there was no significant difference in the number of homicides reported by the three sources (Fisher Exact Test, $p=0.9999$, cases are not enough for a meaningful graph).

\section{Edged weapons}

The number of males murdered with edge weapons was too low for a monthly trend analysis, but the data published by the media were similar to the official data (Chi-squared Test 0.33, $p=0.9878$, Fig. 4).

There were very few females murdered with edge weapons, but again the data published by the media were lower but not statistically different from the official number (Fisher Exact Test, $p=0.9271$, cases are not enough for a meaningful graph).

\section{Other ways to kill}

The number of males murdered with other methods was low and the data published by the media were slightly higher or equal to the official data, but not statistically different (Chi-squared Test 0.86, $p=0.9302$, Fig. 5).

The number of females murdered with other methods was even lower than in the case of males and the data published by the three sources were not statistically different (Fisher exact Test, $p=0.8477$, cases are not enough for a meaningful graph).

\section{Comparison of methods by sex}

When comparing how the victims had died, we found that female victims rates were: edge $11.5 \%$, smother 14.7 $\%$, fire $12.1 \%$. For men, the rates were: edge $6.2 \%$, smother $3.2 \%$, fire $24.2 \%$.

The rates are statistically different for the sexes (Fisher exact Test $p$ values: edge 0.015 , smother 0.000 , fire 0.000 ). Males have a higher probability of dying from fire weapon wounds, followed by edge weapons and less likely by smothering. Women, in contrast, were killed mostly by smothering, secondly by firearms and thirdly by edged weapons (Fig. 6).

\section{Place}

The media published data that were close to the official data regarding where the homicides took place (Fig. 7).

The provinces with more victims were San José, Limón, Puntarenas and Alajuela. Nevertheless, these data can be misleading, because provinces vary greatly in population size. Once corrected for population size, it is clear that Limón has a higher than average homicide rate, while Guanacaste and Heredia have relatively few homicides (Fig. 7).

\section{Nationality}

The reports about the nationality of homicide victims were similar in the media and in the official source (Chisquared Test $6.71, p=0.5682$, Table 1 ). However, the number of foreigners living in Costa Rica varies greatly by nationality. Once corrected for population size, data show that Colombians have an extremely high homicide rate, followed by Panamanians and Nicaraguans; in contrast, Costa Ricans have much lower rates (Fig. 8). 


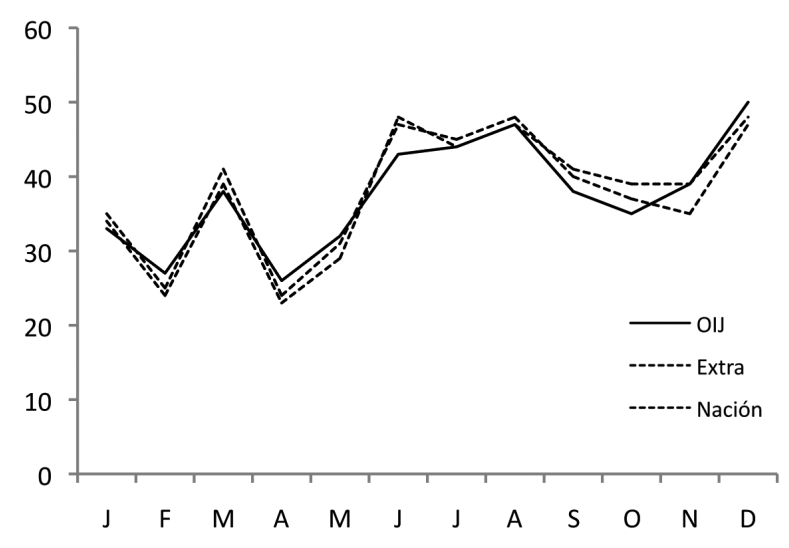

FIG. 1. Total homicides per month in Costa Rica (2008): male victims.

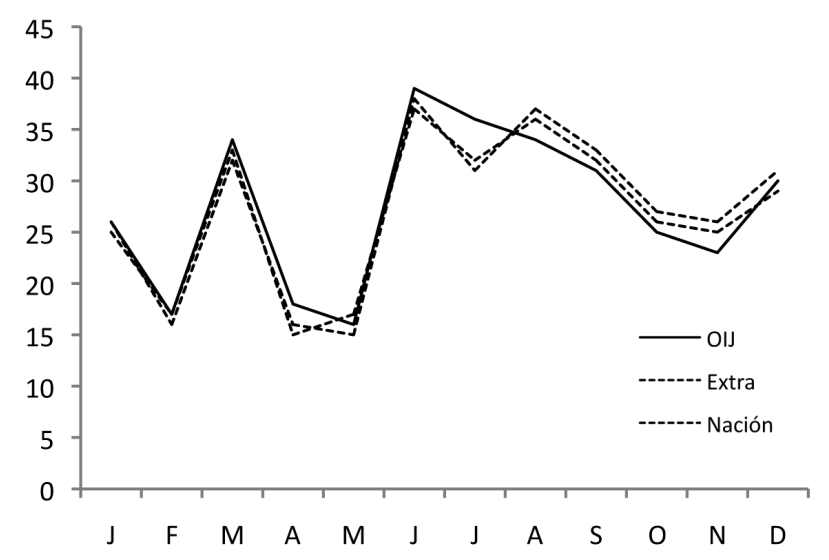

FIG. 3. Total homicides per month with fire weapons in Costa Rica (2008): male victims.

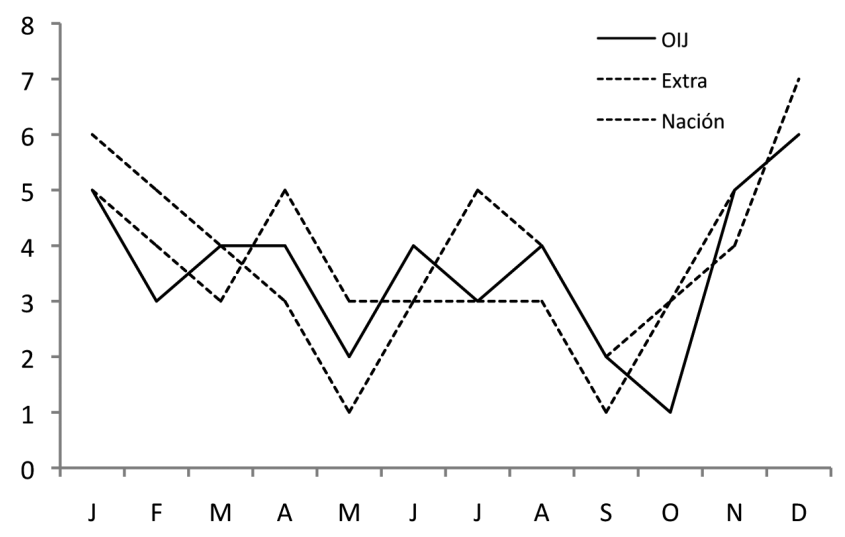

FIG. 5. Total monthly number of males murdered with other methods in Costa Rica (2008).

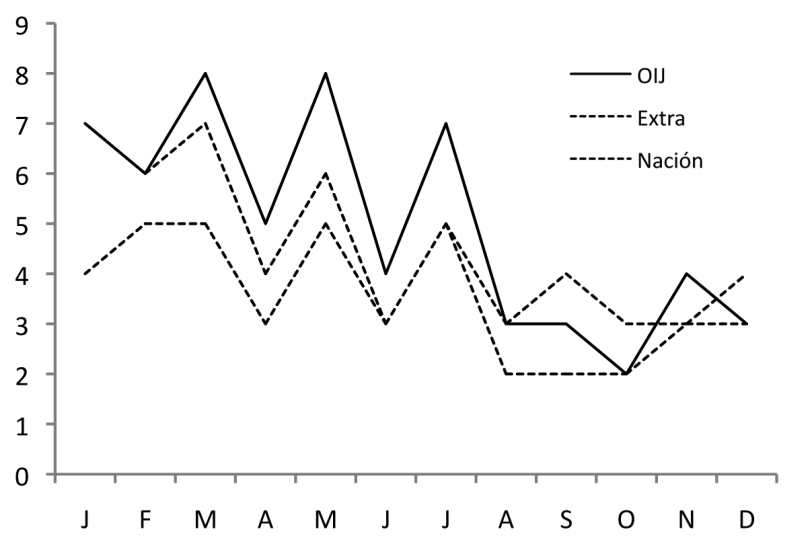

FIG. 2. Total homicides per month in Costa Rica (2008): female victims.

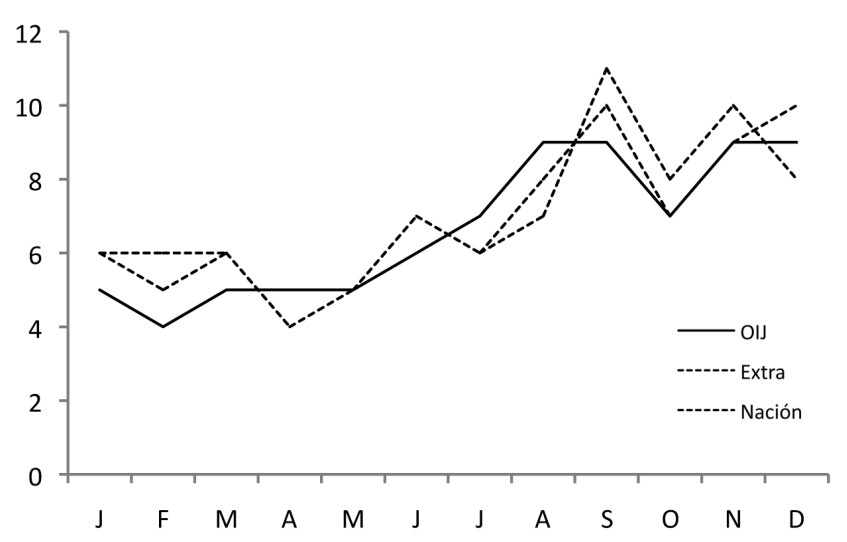

FIG. 4. Total monthly number of males murdered with edge weapons in Costa Rica (2008).

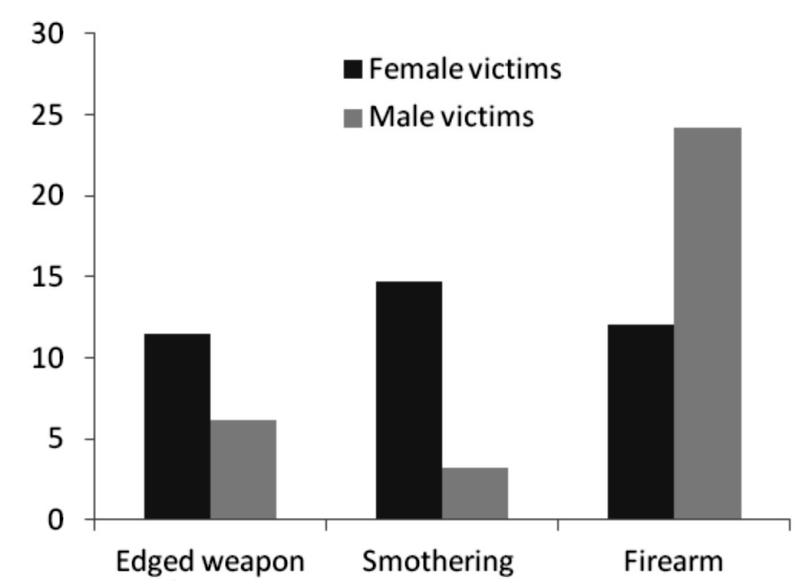

FIG. 6. Percentage of victims by sex and type of homicide for three murder methods (Costa Rica: 2008). 
A

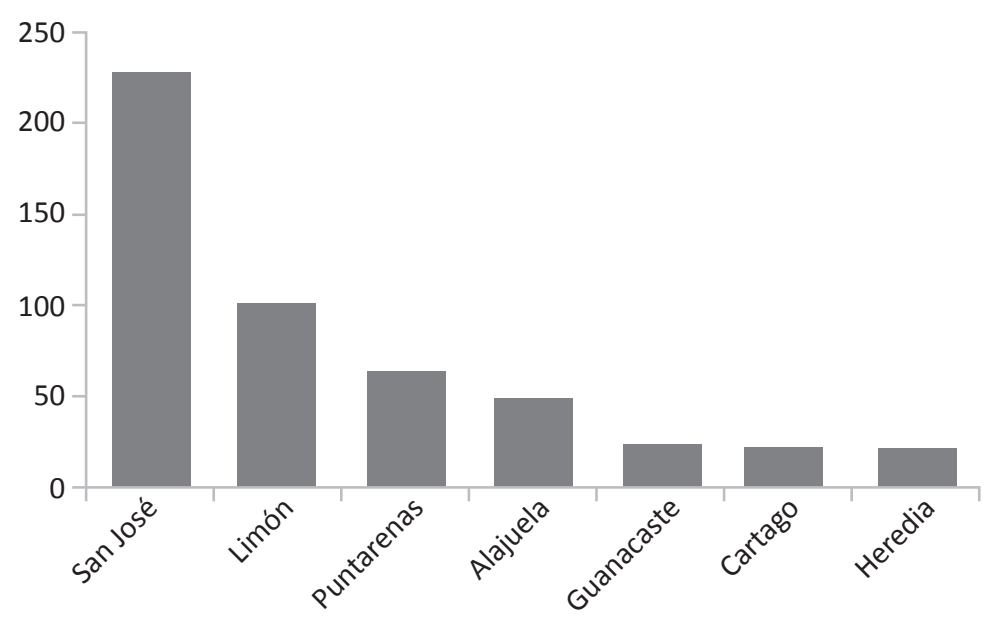

B

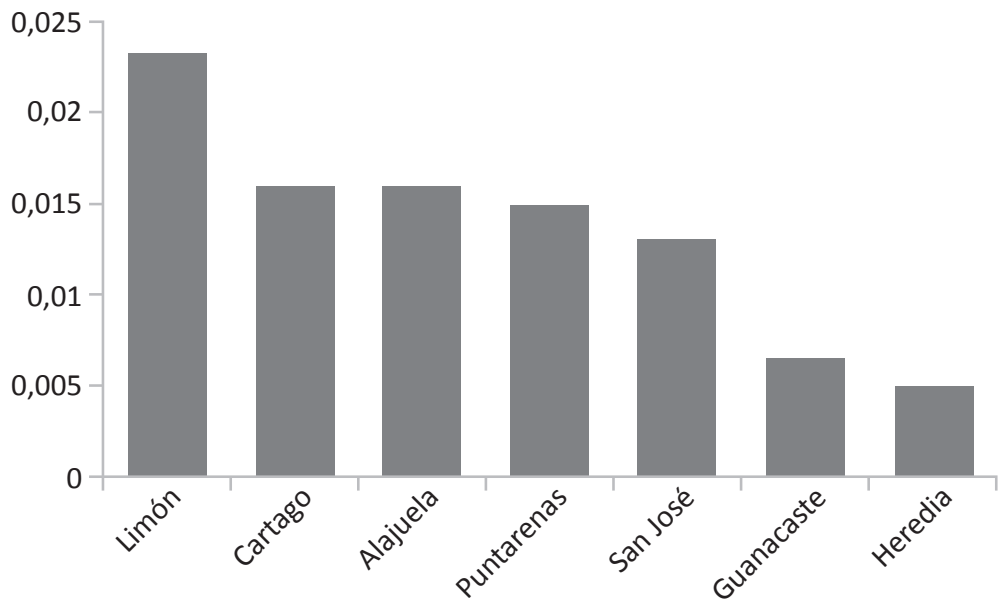

FIG. 7. Total number (A) and rate per 100000 inhabitants (B), of homicides per province in Costa Rica (2008).

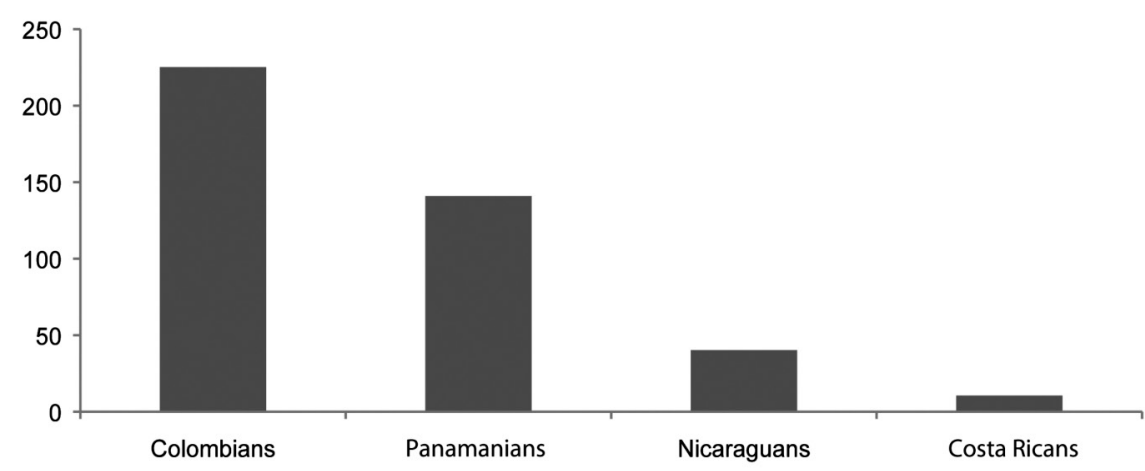

FIG. 8. Homicide rates in 2008 for Costa Ricans and three immigrant nationalities (in all cases, the rate was calculated as murders per 100000 inhabitants of that particular nationality). 


\section{DISCUSSION}

In an important series on the perception of violence in Costa Rica, Huhn $(2005,2008 a, b, 2009)$ found that the public perception of criminality is strongly biased towards two beliefs: the "rising crime wave" and the impunity of criminals. He provides reasons why official statistics can underrepresent criminality and concludes that the rising crime wave and the impunity are not real, but rather they are the probable creations of the media (Huhn 2009). Another study found that the type of crime affects the chances of being mentioned in the media. Homicides are very likely to be in the news, while cases of theft and accidental deaths in traffic accidents were less frequent (PNUD 2006).

Our study does not address if the media mispresents criminality, this has already been studied by Huhn (2005, 2009), who concluded that indeed that exaggeration of the problem is common in the media. Instead, we studied if the media represented correctly the number of homicides, and our result was that they do. The number of homicides published in La Nación and Diario Extra does not differ statistically from the data in the official OIJ report. Apparently the media report nearly a $100 \%$ of homicides because they can help circulation, but they do not report a false number of homicides. However, the media could manipulate the information by using larger fonts, colors, more images, longer articles and more space per page for information on homicides and other forms of criminality. This possibility needs to be addressed in future studies. The kind of language can also be used to manipulate and this would require an "analysis of discourse". There are political reasons why people in power can boost false information about criminality. Jenkins (1994) and Huhn (2009) documented how the OIJ has increased its staff beyond the growth of criminality.

Most homicide victims are adult men who are related with drugs (including alcohol), and most die on weekends and during the night (Cruz 1999, Sáenz 2006, Vargas \& Solano 2009). These results led us to hypothesize that the months with several holidays, when alcohol consumption and nocturnal activity increase, would be the months with highest homicide rates. For unknown reasons, this was not the case. Perhaps we are wrong in our assumption that holiday strings have a higher alcohol consumption and more nocturnal activity because people do not worry about having to leave early for work the next day, or-more probably- the situation is more complex. In any case, this is a good subject for future research.

Killing is not limited to humans, it is widespread among all organisms, including plants. Killing is widely documented in all primates, and the most recent model on homicides states that there is an evolutionary arms race between homicidal strategies and anti-homicide defenses (Duntley \& Buss 2011). Homicides are triggered by psychological mechanisms that are activated only under particular circumstances, and vary with the individual. Furthermore, female assassins are more likely to kill infants, while male assassins are dangerous for a larger variety of potential victims in which sex plays an important role (Duntley \& Buss 2011). In Costa Rica, $40 \%$ of murdered women are victims of their sex partners and $26 \%$ are killed by family members (Anfossi 2002), probably in sex related conflicts, fully in agreement with the model proposed by Duntley \& Buss (2011). While Costa Rican female victims that survived escaped mostly from attacks with edged weapons in a study done ten years ago (Carcedo \& Sagot 2002), the data from 2008 show that those who were killed died mostly by smothering, secondly by firearms and thirdly by edged weapons. This might mean that women are more likely to escape from edged weapons than from smothering, but we ignore if data are reliable, because some of the surviving victims may not have asked for support in the organization that collected the data (Carcedo \& Sagot 2002).

We found a clear difference in the way women and men are killed. On the average, men have more muscle power than women, and this can explain why women are more likely to be smothered than men, which are more difficult to overcome and thus are more likely to be attacked with fire or edged weapons. This result also is in agreement with the model proposed by Duntley \& Buss (2011).

Our results are similar to those of Huhn (2009), who worked with the 2007 statistics and found a country homicide rate close to 8 per 100000 , high rates for the port and capital provinces and lower rates for Heredia, Alajuela and, specially, Cartago. Our study of the 2008 statistics found similar results, but in our case Heredia had the lowest rate. This small year to year variability is to be expected because we are dealing with complex phenomena.

Homicide is a major source of excess mortality among Nicaraguan-born immigrants versus Costa Rican natives, independently of their sex (Herring et al. 2008). We are aware of no equivalent studies of mortality of Colombian immigrants, but our results indicate an extraordinarily high rate of homicide among Colombian immigrants. In both cases, the results agree with previous studies which concluded that lack of employment opportunities, local drug markets, the availability of firearms (perhaps associated with a recent past of civil war) and widespread use of alcohol (all present among immigrants) are related with homicide rates (Briceño-León et al. 2009). 


\section{ACKNOWLEDGEMENTS}

We thank Bernal Morera (Universidad Nacional, Costa Rica) and Vanessa Nielsen (Universidad de Costa Rica) for suggestions to improve the manuscript, and Katya Calderón (Universidad Estatal a Distancia) for suggesting the study of homicides and the press.

\section{REFERENCES}

Aguilar, T. 2001. Violencia simbólica en los medios de comunicación: los casos de violencia intra familiar y la cobertura de la prensa escrita costarricense. Medicina Legal de Costa Rica 18: 47-56.

Anfossi, K. 2002. Femicidio en Costa Rica. Radio Internacional Feminista - FIRE. Sociologías 8 (www.fire.or.cr/etabnov99.htm, downloaded March 28, 2012).

Briceño-León, R. 2008. La violencia homicida en América Latina. América Latina Hoy 50: 103-116.

Briceño-León, R.A. Villaveces \& A. Concha-Eastman. 2009. Understanding the uneven distribution of the incidence of homicide in Latin America. GIGA German Institute of Global and Area Studies. GIGA Working Paper 108.

Carcedo, A. \& M. Sagot 2002. Femicidio en Costa Rica: balance mortal. Medicina Legal de Costa Rica 19: 5-16.

Cruz, J.M. 1999. La victimización por violencia urbana: niveles y factores asociados en ciudades de América Latina y España. Revista Panamericana de Salud Pública 5: 259-267.

Duntley, J. \& D. Buss. 2011. Homicide adaptations. Aggression and Violent Behavior 16: 399-410.

Herring, A.A., R. Bonilla-Carrión, R. Mae \& K. Hailey. 2010. "Special Focus: Immigration Worldwide". Differential Mortality Patterns Between Nicaraguan Immigrants and Nativeborn Residents of Costa Rica. Journal of Immigrant and Minority Health 12: 33-42.
Huhn, S. 2005. Einwanderungsdiskurse und Migrationspolitik in Costa Rica. Wan-del und Konstanten in der gesellschaftlichen Auseinandersetzung mit der nikaraguani- schen Migration seit den 1980er Jahren. Beiträge zur Lateinamerika-Forschung 18: n.p.

2008a. Discourses on Violence in Costa Rica, El Salvador, and Nicaragua: Social Perceptions in Everyday Life, GIGA Working Paper, №. 81, Hamburg: GIGA.

2008b. A History of Nonviolence: Insecurity and the Normative Power of the Imagined in Costa Rica, GIGA Working Paper, No. 84, Hamburg: GIGA.

2009c. Contested Cornerstones of Nonviolent National Self-Perception in Costa Rica. A Historical Approach, GIGA Working Paper, №. 101, Hamburg: GIGA.

Jenkins, P. 1994. Using Murder: The Social Instruction of Serial Homicide. Aldine de Gruyter, Hawthorne, New York, USA.

Lester, D. 1995. Suicide and homicide in Costa Rica. Center for the Study of Suicide, Blackwood, NJ 08012, USA. Medicine Science and the Law 35: 316-318.

PNUD (Programa de Naciones Unidas Para el Desarrollo). 2006. Informe Nacional de Desarrollo Humano 2005. Venciendo el temor. In seguridad ciudadana y desarrollo humano en Costa Rica, San José: PNUD.

Sáenz, M.A. 2006. Los Homicidios Dolorosos en Costa Rica: Caracterización Sociodemográfica. Revista de Ciencias Sociales 111: $177-188$

Sagot, M. \& A. Carcedo. 2010. When Violence Against Women Kills: Femicide in Costa Rica, 1990-1999, p. In R. Fregoso \& C. Bejarano (eds.). Terrorizing Women: Feminicide in the Americas. Duke University, Durham, North Carolina, USA.

Vargas, M.S., L. Solano \&R. Bonilla. 2009. Análisis Médico Legal de los homicidios en Costa Rica en el 2008. Medicina Legal de Costa Rica 26: 7-27.

Zar, J.H. 1998. Biostatistical Analysis. Prentice Hall, New Jersey, USA.

\section{Article edited by Bernal Morera}


